\title{
Perpetual anarchy: From economic security to financial insecurity
}

\author{
S.M. Amadae \\ Massachusetts Institute of Technology, USA
}

Marieke de Goede argues that there has traditionally been a close relationship between finance and both national security and the economic security of nations. Hence, "finance cannot be understood to be a new security concept" (Goede, 2010: 109, emphasis in original). This is because financial soundness is essential to individual and national economic security, and fiscal wherewithal is crucial to maintaining military presence. The smooth functioning of an economy enables the funding of military protection. Conversely, as the recent global financial crisis once again demonstrated, national sovereignty itself depends on economic solvency that is a function of the prudential financial management of firms and governments. De Goede discusses this two-directional relationship with respect to how finance plays an instrumental role in making it possible to maintain national security, and how finance itself directly relates to the viability of households and nations, which require a positive balance of outputs against inputs. She also addresses a third way to consider the relationship between finance and security in view of their historical and conceptual entanglement. From this perspective, the development of modern nation states is inseparable from financial instruments including, for example, those of sovereign debt. Considered historically, after World War II financial tools evolve, and "risk comes into focus as a technique [insofar as it is quantified] that bridges finance and security" (de Goede, 2010: 107, emphasis in original).

In addressing the overarching question of what is novel in the relationship between finance and security, de Goede hones in on two recent phenomena that are helpful to put into relief against a longer timeline. These include President Barack Obama's response to the financial crisis, which deployed the rhetoric of national security in order to securitize global credit insolvency, as well as efforts to address the financial dimension of terrorism by targeting assets and controlling global finance so as to isolate terror networks. Thus the question of the relationship between security studies and finance takes on the problematic of whether there is a perennial dialectic of employing economics to secure military power on the one hand, and directly harnessing "financial instruments to ... engender business security" on the other (de Goede, 2010: 109). The constancy of this dynamic is underscored by de Goede's dismissal of the end of the US commitment to a gold standard to back its fiat money in 1974 as the pivotal action underlying subsequent economic instability. Economic recession and depression have 
characterized modern political economy since the Enlightenment. Thus, economic and national security are interdependent, and their relationship evolves as societies develop new institutions and financial tools that alter possibilities for organization and interaction.

My remarks here address two major themes in de Goede's 2010 essay on 'Financial security'. First, the relationship between stable markets and the proverbial 'security dilemma', often formulated in terms of Thomas Hobbes' (1991) state of nature; and second, the development of new decision-technologies to address risk in the post-World War II period. The disciplinary expertise I bring to bear on this discussion is that of political theory and science, technology, and society studies, the latter of which focuses on the development of sources and practices of expertise directed to governance. The two themes are here confluent because the new risk management techniques stemming from rational expectations and rational decision theory represent a re-evaluation of the security dilemma and its relationship to the rule of law governing market relations.

\section{The security-finance dialectic}

During World War II, the atomic bomb, computation, and game theory were invented as a consequence of the felt necessity to achieve security through combining strategic planning with weapons of unprecedented mass destruction (Amadae, 2016; Erickson, 2015; Erickson et al., 2013; Thomas, 2015; Mirowski, 2003). The US was able to achieve this due to its awesome wartime economic productivity, and the arrival of European émigrés who faced oppression by the German National Socialist regime. Theorists who were engaged in active WWII roles invented the techniques for quantifying risk and the treatment of decision-making as an economic exercise (von Neumann and Morgenstern, 1944; Leonard, 1992). Those working in this new theoretical tradition of expected utility theory and game theory turned the classical liberal relationship between security and markets upside down. Whereas, as de Goede recounts, financial security enabled military power and itself resulted from the sound use of economic instruments, in the aftermath of WWII and the ensuing Cold War era, political and economic security were repositioned to derive from rational decisions which are in principle all subject to fiscal stipulation. Following this theoretical trajectory, by the $1980 \mathrm{~s}$ in the US, the achievement of national security and economic stability were both studied and enacted as products of strategic rationality (Schelling, 1960, 1978; Arrow and Debreu, 1954; Axelrod and Keohane, 1985; Brams, 1984).

This observation does not detract from de Goede's points of argument. Financial wherewithal purchases military might. Sound decisions are necessary for business security and solvent government institutions. History demonstrates the inseparability of financial securities and those institutions used to manipulate threats of violence to achieve national security. The science of rational expectations underlies making rational decisions alike in decisions pertaining to uncertain futures in military strategy and finance. But whereas de Goede's argument is structural, my position is dialectical. This is because the developmental process was dialectical. The atomic bomb altered security relations among world states. This new material power of mass destruction could only be marshaled to achieve security within a theory of rational deterrence. Thus game theory and rational expectations, which had prestige for informing strategic policy, provided a foundational means to reconceptualize individual behavior. By postulating that all rational action is strategic, game theory undermines the modern liberal project of cooperatively attaining mutual security, whether military or economic. Crucially, as de Goede notes, there is a shift from the actuarial systems of addressing future 
possibilities in modern capitalism to the technologies of risk management in post-modernity. The former were designed to ensure a pool of resources available to compensate insured individuals given the statistical incidences of bad outcomes in a membership population. The latter instead assume that self-interested action will develop and sustain those institutions that effectively mitigate risk as long as incentive structures are appropriately applied by governance.

De Goede (2010: 103) describes the evolving use of the term "security", initially "denoting a pledge or a property deposited to secure the fulfillment of an obligation" in the fifteenth century, and subsequently referring to financial tools themselves as securities. Within this latter lexicon, financial media, such as futures and options, enable businesses to place a monetary value on risk which can then be traded as a commodity, and thus in principle allow communities to mitigate the destructive repercussions of bad outcomes with poor financial returns. If risk is accurately priced, then insuring against it should supply the capital necessary to offset the eventuality of loss. As de Goede (2010: 103) puts it, "finance and investment became cast as techniques through which responsible individuals ... were able to secure their family's financial futures".

The process of securitization, or the "process by which financial assets, for example loans, mortgages and credit card receivables are repackaged and resold in the financial markets ... [and hence] turned into tradable securities" (de Goede, 2010: 104), took a new turn in the 1980s when deregulation permitted banks to unify household finance with largescale capital investment. As we recall with hindsight, the justification for the development of these security assets was their dual rationale of alleviating risk while simultaneously yielding "handsome profits" (de Goede, 2010: 104). We also know now that as a matter of fact, "the securitization of finance ... has helped introduce spectacular insecurity in economic life" (de Goede, 2010: 104, emphasis in original). This is because these practices, relying on complex algorithmic programs beyond the understanding of their managers, repeatedly led to systemic breakdowns of economic solvency. This resulted in dramatic losses and the need for external governmental intervention to maintain market order.

That financial tools designed to hedge risk themselves resulted in economic losses and systemic collapse raises the question of how to account for their failure. The Nobel Prize winning economist Kenneth J. Arrow, in particular, proposed that everything could be assigned a market value and traded, including future prospects. Were these tools misconceived? Alternatively, were these products abused by strategic actors who sought to utilize them in their own narrow self-interest, eventually compromising general market solvency? These questions loom over early twenty-first century economics as a means to achieve financial security. The theory underlying these practices supposes that market actors serve narrow selfinterest and that risk would be contained through its accurate pricing. In keeping with standard 'invisible hand' thinking (Aydinonat, 2008), individual self-interest only unintentionally results in overall economic stability and prosperity. Either risk was inaccurately priced through imperfect practices, or the invisible hand hypothesis as applied to risk management through free market trade is flawed.

I agree with de Goede that the end of the US commitment to the gold standard, and the turn to virtual money, does not provide the explanation for why Cold War risk management technologies have proven to be so catastrophically flawed. Yet I remain concerned that accepting financial and national security to be perennially intertwined does not rise to the occasion of providing a cogent account of the new failures to secure international financial stability by using those late twentieth-century security innovations tasked to deliver it. Thus I develop an alternative hypothesis - that the reconceptualization of finance along the lines of 
risk management, twinned with those practices the new security technologies rationalized, resulted in their inverse: systemic and catastrophic precarity. The key point is that throughout modern political economy, the physical security dilemma of mutual insecurity of assault, and the economic security dilemma of famine, were cleverly countered through two means that have been abandoned in late modernity. These are mutual respect of others' rights to personhood and property, and the overarching stance that financial institutions must serve the public interest to be legitimate (Hont and Ignatiev, 1983).

\section{Classical and modern liberalism}

Since the time of Adam Smith, European and North American political economy deemed secure property rights and the just rule of law essential to markets. Market exchange in turn provided the basis for personal and national economic security. The rational choice revolution initiated by John von Neumann and Oskar Morgenstern's (1947) theory of expected utility provided the means to reconceptualize instrumental rationality and to ground the new practices of risk management. Their work was path breaking on two fronts. One was on individual decision-making in contexts with risk (i.e., estimable odds). The other was on decision-making involving two or more other strategic rational actors, who must consider each other's preferences and strategies. According to classical liberal political and economic theory, the decisive conceptual distinction between economic security and political security is that whereas the former was viewed as parametric - single actors with instrumental goals and without strategic competition - the latter was viewed as strategic. Another way to state this is that police and armies defend against attack from other human agents, whereas in market institutions individuals cooperatively exchange without threatening to harm one another.

Under classical liberalism, relinquishing de facto possession in favor of mutual recognition of the elementary rights of personhood, property, and private contacts meant that voluntary compliance reduced the need for the application of coercive force to incentivize trade (Locke, 1988). Compliance stemmed from individuals' acquiescence to agreements personally made and the accepted legitimacy of the laws regulating the state. Hence, although a necessary component of maintaining a national government is its monopoly over the power of enforcement, this power must be accompanied by legitimacy and the widespread voluntary compliance this fosters. Thus, modern liberal market practices were in line with the negative virtue ethics of individuals' perfect duty to uphold the no harm principle (Smith, 1759; Kant, 1999; Rawls, 1970; Nozick, 1975). State government promotes market exchange through impartial, predictable law that rewards individuals' initiative to better their own conditions (Smith, 1776; Rothschild and Sen, 2006; Sachs, 2016). This rule of law will not require excessive and expensive recourse to the domestic use of force as a consequence of its promotion of citizens' interests informally aggregated into a generalized 'public good' (Smith, 1776). This in turn, which Adam Smith refers to as the 'system of natural liberty', secures a sound political economy that achieves individual and national economic security, and even prosperity. Such a system also provides a sufficient tax base to pay for military, police, transport and justice. And under the model of modern Westphalian sovereignty, nations similarly constituted have no cause to go to war with one another because they respect each other's right to existence (Krasner, 1999). International relations are thus conducted through the exchange of goods instead of armed conflict.

Under modern liberalism, safety among people was achieved by their mutual recognition and abeyance of assault, theft, and reneging on agreements. Economic freedom is pursuant 
to achieving this political economic order formalized under the rule of law that stipulates ambiguities and applies punitive sanctions among deviant transgressors. Under perfect competition, market transactions do not involve strategy because actors cannot unilaterally affect prices. Physical security is voluntarily ceded to others. Economic security is achieved because in aggregate, competition to profit from exchange lowers the cost of living for all members of society (Hont and Ignatief, 1983). Mutual recognition is a precondition for exchange and for price setting, because without minimum mutual respect the alternative may be theft. Hence the free market order depends on having already achieved security of personhood, property, and contractual arrangements. Thus, the free market order depends on non-instrumental virtues, the most prominent being the perfect duty not to harm and the imperfect duty of beneficence underlying charity (Smith, 1759; McCloskey, 2016).

\section{Neoliberal financialization}

The rational choice revolution upended classical liberalism and the modern production of economic prosperity from first having settled the security dilemma, which coincided with the codification of legitimate rule of law. The rationality project treats both physical and economic concerns as fundamentally strategic. This is a shift away from Adam Smith, for whom the free market conditions of perfect competition by definition require that no individual or firm can unilaterally alter market prices for any commodity. For game theorists, who view economic exchange as fundamentally strategic, economic transactions and the rule of law are both best characterized as modes of interpersonal conflict without boundaries. Specifically, no agent recognizes the boundary of a no-harm principle to constrain his or her actions. According to rational choice theory, this is because harm is possibly the product of actions with probabilistic consequences. Moreover, even were a definition of harm to be widely accepted, still no one would be motivated to uphold it as soon as the personal costs outweighed the gains.

Thus, under modern liberalism, the achievement of domestic peace and the clear and just rule of law is the necessary precondition for economic prosperity (Smith, 1759), which in turn facilitates sufficient market wealth to procure adequate military defense. In contrast, following the rise of rational choice theory (which is a combination of rational expectations and strategic interaction), all decision-making involving other people is necessarily strategic and often probabilistic. The rule of law is unabashedly the product of narrow individual self-interest and the differential power of actors (Buchanan, 1975). Political and economic relations are characterized as strategic competition and coercive bargaining that flaunts the no-harm principle because actors levy credible threats to achieve favorable terms. The modern interdependence of national security and national finance is thus reframed. Personal security under just law as a precondition for market order is replaced by perpetual physical and financial insecurity. Harm can be to individuals' mortality, and can involve a deterioration of prospects for longevity and morbidity (Schelling, 1968). Individuals are responsible for their livelihood in a system of incessant strategic conflict characterized by no exit, coercive bargaining, and the absence of any safety net. Whereas precarity most affects lower income earners and those who are unemployed, no agent feels safe. As the economist David Kotz reports in analyzing late-modern neoliberalism, even at the level of chief executive officer, individuals cannot exit a relentless state of insecurity. This heightened sense of the implacable nature of competition is passed on to chief executives who, according to Jeffrey Garten, Dean of Yale's School of Management, "feel they are in a brutally competitive world, and they think they are in a race for their lives" (quoted in Kotz, 2016: 21). 
Under the late-modern view of economics, rooted in game theory and widely accepted across the Anglo-American social sciences by the 1980s, every interaction is strategic, and every outcome has a price. Thus, according to Arrow's general equilibrium theory, which is closely associated with the Efficient Market Hypothesis $(\mathrm{EMH})$ that rationalized deregulating and pricing risk in all markets as the means to providing insurance for transactions, no consideration falls outside rational expectations (Fama, 1991). As de Goede acknowledges, considering Arrow's work through the perspective of a contemporary journalist: "[Arrow] had a vision of a world in which everything was assigned a value on a market. In this utopia, every possible state of the world, past, present and future, from a stormy July evening in Patagonia to England winning the World Cup had a financial payoff associated with it" (Goede, 2010:105, quoting from Dunbar, 2000).

\section{Financializing security: Economic and military}

In view of the 2008 financial collapse that tested Arrow's general equilibrium theory and the $\mathrm{EMH}$, we can pose the deeper question of whether the practices these theories guided were imperfect, or if the new financial security theories ostensibly hedging risk through selling it in unregulated markets were themselves flawed, hence obtaining poor outcomes when implemented? Posing this question recognizes that the new financial tools of risk management stemming from von Neumann and Morgenstern's expected utility theory and its successors in Savage's and Bayes' theories, and viewing market exchanges as fundamentally strategic rather than perfectly competitive, may be best recognized as a new chapter in the historical relationship between national and economic security.

De Goede contemplates this idea and assesses how rather than successfully quantifying and managing risk, this new approach to financial markets and tradable securities instead indefinitely multiplies risk by both fetishizing it and proliferating it as a profitable good with exchange value. As she observes,

\footnotetext{
... the tamed future is not commercially profitable. Rather than an eradication of risk in the markets, financial instruments are more properly understood as a modern embracing of risk, whereby the identification of uncertain futures enables commodification of the present. (de Goede (2010: 105, emphasis in original)
}

Here de Goede suggests that risk management promotes flirting with hazard and harnesses this as a good for private profit, rather than through the impartial design of financial institutions built to mitigate risk for all members of the public. From this perspective, the encompassing market-wide risk of collapse cannot be forestalled, without perfectly counterleveraged incentives, because it is a public good of inclusive economic security that private actors have the perpetual incentive to free ride on for personal gain. The only antidote is an overarching system of monitoring and heavy-handed governance that achieves regulatory compliance via the effective mobilization of punitive threats. Since many of the large banks issuing security products influence market prices for risk, this market is not one of perfect competition. Game theory accepts that market transactions are strategic. Rather than relying on impartial institutions to foster the perfect competition that guarantees a good outcome of encompassing financial security, strategic competition relies on the appropriate incentive structure to achieve Pareto efficient outcomes. This means that free riding outcomes by which some (such as the financial sector) gain at the expense of others (such as holders of pension accounts) must be countered by effective institutional design. 
This financialization of all value, including risk, has the implication of enabling some, especially those agents who are well positioned to either create laws in their favor or alter market prices by their actions, to build a casino style economy. Whereas this economic treatment of value looks like an equal playing field, it actually maintains significant structural asymmetries of power to reap rewards. Moreover, this financial system cannot exit from the two-fold physical and economic security dilemma that classical liberals deftly navigated. This is because game theory has the triple implication of rendering every decision subject to strategy, treating it as a matter of quantifying risk, and hence of pricing it. Additionally, no action can be evaluated from any other perspective beside that of its outcome vis-à-vis personal, individual self-gain. This negates alternative logics of action. Most crucially, strategic rationality denies the possibility for acting on ethical considerations that evaluate the merits of action independent from their consequences, such as counting accurately and upholding legal standards impartially. Moreover, treating risk as a good to be traded for personal advantage loses sight of the original liberal project of achieving inclusive physical and economic prosperity. Such a project aimed to build a system that could quell harmful conflict and institute an impartial system of law and order through which to offer citizens recourse if they have been violated. In contrast, when the large banks were bailed out during the 2008 financial crisis, members of the public paid the price, hence insuring the profitability of big finance at the expense of lower-tier income earners around the world.

In conclusion, I concur with de Goede that national and economic security, at the level of individuals and states, are interdependent. Also, they are expressed and developed in specific historical and cultural contexts. Thus, as neoclassical economics and the Keynesian policies of the Great Moderation following WWII yielded to the neoliberal economics of risk management in the late 1970s, a new constellation of financial versus physical security relations emerged. This transformed conceptual and practical regime is the result of a Faustian bargain with states exercising power as nuclear Leviathans. They wield thermonuclear bombs like a new sword of Damocles, which leaves us perpetually and immanently vulnerable, while they are rationalized by a deterrence theory that effectively renders intelligibility superfluous to action (Amadae, 2018). Specific theorists and schools of thought articulating these new practices include Thomas C. Schelling (1960; 1968), who applied game theory to nuclear deterrence and anticipated the neoliberal-institutionalist school of International Relations, as well as James Buchanan (1975) of the public choice school, Douglass North (1991) of the new institutional economics, and Gary Becker and Richard Posner (2009) of law and economics. All rely to varying degrees on rational expectations, risk management, and strategic interaction. These present novel means to conceptualize how to achieve domestic and international peace as well as economic growth (the preferred means for achieving economic security). Rather than alleviating the challenge of mutual conflict and harm through voluntarily desisting, instead harm can only be avoided by applying effective incentives. This can be in the form of state issued threats or coercive peer-pressure via shaming or vigilantism, or of designing policies with positive implications for improving the longevity and morbidity levels in a population (Schelling, 1968).

It behooves us to be aware that the neoliberal economics, to which Michel Foucault (2010) drew attention as mandating self-care in the form of self-responsibilization, recrystallizes the relationship between the two forms of security. Formerly classical liberalism, which although never entirely freed from the violence of exclusion of non-members from due consideration, initially at a minimum legally defended recourse from harm, and then increasingly also guaranteed freedom from want via a progressive social welfare platform. However, the Cold War reaction to the Keynesian social welfarist agenda, sponsored by the 
Mont Pelerin Society (Mirowski and Plehwe, 2012), the public choice school (MacLean, 2017), and law and economics withdrew both guarantees: first of economic security and a safety net; and second of physical security. The latter step has been rationalized under the logic of risk management, which treats harm as a statistical likelihood of ill repercussions without a clear channel of causal responsibility and assignation of blame. No individual has an inherent right to any level of mortality. Furthermore, given the pricing of all risks that extend to the value of a statistical life (or cost to reduce one members' morbidity randomized across a population), the price for harm, or its reduction, is simply what it costs to move from the status quo.

At the moment the status quo accepts the impossibility of cooperating among allies unless their interests perfectly align, and this will most likely be only as a temporary coalition. It also accepts a nuclear-industrial complex compliant with 7,000 thermonuclear weapons on hair-trigger alert status in the hands of Donald Trump and Vladimir Putin alone. Until we jointly wrestle with the nuclear security dilemma and write a new narrative about the possibility of cooperation, the main role of finance will be to continue bankrolling perpetual nuclear and military brinkmanship rather than generating a sustainable financial infrastructure for a shared future.

\section{References}

Amadae, S.M. (2003) Rationalizing Capitalist Democracy: The Cold War Origins of Rational Choice Liberalism. Chicago, IL: University of Chicago Press.

Amadae, S.M. (2016) Prisoners of Reason: Game Theory and Neoliberal Political Economy. Cambridge: Cambridge University Press.

Amadae, S.M. (2018) Computable rationality, NUTS, and the Nuclear Leviathan. In: Bessner, D. and Guilhot, N. (eds.) The Decisionist Imagination: Democracy, Sovereignty and Social Science in the 20th Century. New York, NY: Berghahn Books, in press.

Arrow, K.J. and Debreu, G. (1954) Existence of an equilibrium for a competitive economy.

Econometrica, 22(3): 265-90.

Axelrod, R. and Keohane, R.O. (1985) Achieving cooperation under anarchy: Strategies and institutions. World Politics, 38(1): 226-54.

Aydinonat, N.E. (2008) The Invisible Hand in Economics: How Economists Explain Unintended Social Consequences. London: Routledge.

Becker, G.S. and Posner, R.A. (2009) Uncommon Sense: Economic Insights, From Marriage to Terrorism. Chicago, IL: University of Chicago Press.

Brams, S.J. (1985) Superpower Games: Applying Game Theory to Superpower Conflict. New Haven, CT: Yale University Press.

Buchanan, J.M. (1975) The Limits of Liberty: Between Anarchy and Leviathan. Chicago, IL: University of Chicago Press.

de Goede, M. (2010) Financial security. In: Burgess, J.P. (ed.) The Routledge Handbook of New Security Studies. London: Routledge, 100-109.

Dunbar, N. (2000) Inventing Money: The Story of Long-Term Capital Management and the Legends Behind It. New York, NY: John Wiley.

Erickson, P. (2015) The World the Game Theorists Made. Chicago, IL: University of Chicago Press.

Erickson, P. et al. (2013) How Reason Almost Lost Its Mind: The Strange Career of Cold War

Rationality. Chicago, IL: University of Chicago Press.

Fama, E.F. (1991) Efficient capital markets: II. The Journal of Finance, 46(5): 1575-617.

Foucault, M. (2010) The Birth of Biopolitics: Lectures at the Collège de France, 1978-1979.

Basingstoke: Palgrave Macmillan. 
Friedman, M. and Savage, L.J. (1948) The utility analysis of choices involving risk. Journal of Political Economy, 56(4): 279-304.

Friedman, M. and Savage, L.J. (1952) The expected-utility hypothesis and the measurability of utility. Journal of Political Economy, 60(6): 463-74.

Hobbes, T. (1991) Leviathan. Cambridge: Cambridge University Press.

Hont, I. and Ignatieff, M. (1983) Editors' introduction. In: Hont, I. and Ignatieff, M. (eds.) Wealth and Virtue: The Shaping of Political Economy in the Scottish Enlightenment. Cambridge: Cambridge University Press, 1-44.

Kant, I. (1999) Metaphysical Elements of Justice: Part I of the Metaphysics of Morals. Indianapolis, IN: Hackett.

Kotz, D.M. (2015) The Rise and Fall of Neoliberal Capitalism. Cambridge, MA: Harvard University Press.

Kotz, D.M. (2016) Neoliberalism as the framing concept for contemporary capitalism. Manuscript prepared for American Political Science Association meetings, Philadelphia, September 2016.

Krasner, S.D. (1999) Sovereignty: Organized Hypocrisy. Princeton, NJ: Princeton University Press.

Leonard, R.J. (1992) Creating a context for game theory. History of Political Economy, 24: 29-76.

Leonard, R.J. (2010) Von Neumann, Morgenstern, and the Creation of Game Theory: From Chess to

Social Science, 1900-1960. Cambridge: Cambridge University Press.

Locke, J. (1988) Two Treatises of Government Student Edition. Cambridge: Cambridge University Press.

MacLean, N. (2017) Democracy in Chains: The Deep History of the Radical Right's Secret Plan for America. London: Scribe.

McCloskey, D.N. (2016) Bourgeois Equality: How Ideas, Not Capital or Institutions, Enriched the World. Chicago, IL: University of Chicago Press.

Mirowski, P. (1989) More Heat than Light: Economics as Social Physics, Physics as Nature's Economics. Cambridge: Cambridge University Press.

Mirowski, P. (2003) Machine Dreams: Economics Becomes a Cyborg Science. Cambridge: Cambridge University Press.

Mirowski, P. and Plehwe, D. (eds.) (2012) The Road from Mont Pèlerin: The Making of the Neoliberal Thought Collective. Cambridge, MA: Harvard University Press.

Neumann, J.v. and Morgenstern, O. (1947) Theory of Games and Economic Behavior. Princeton, NJ: Princeton University Press.

North, D.C. (1990) Institutions, Institutional Change and Economic Performance. Cambridge: Cambridge University Press.

Nozick, R. (1974) Anarchy, State, Utopia. New York, NY: Basic Books.

Rawls, J. (1970) A Theory of Justice. Cambridge, MA: Belknap Press.

Rothschild, E. and Sen, A. (2006) Adam Smith's economics. In: Haakonssen, K. (ed.) The Cambridge Companion to Adam Smith. Cambridge: Cambridge University Press, 319-65.

Sachs, J.D. (2016) Happiness and sustainable development: Concepts and evidence. World Happiness Report 2016. Available at: <http://flexclay.com.au/wp-content/uploads/2016/07/report1.pdf>. Accessed 12 December 2017.

Schelling, T.C. (1960) Strategy of Conflict. Cambridge, MA: Harvard University Press.

Schelling, T.C. (1968) The life you save may be your own. In: Samuel B. Chase, S.B.Jr (ed.) Problems in

Public Expenditure Analysis. Washington, DC: Brookings Institution, 127-62.

Schelling, T.C. (1978) Micromotives and Macrobehavior. New York, NY: W.W. Norton \& Co.

Smith, A. (1982/1759) The Theory of Moral Sentiments. Indianapolis, IN: Liberty Fund.

Smith, A. (1776) An Inquiry Into the Nature and Causes of the Wealth of Nations. Volume 1. W. Strahan and T. Cadell, in the Strand.

Thomas, W. (2015) Rational Action: The Sciences of Policy in Britain and America, 1940-1960. Cambridge, MA: MIT Press. 